\title{
Penerapan Teknik Akrostik dalam Pembelajaran Menulis Puisi Pada Siswa Sekolah Dasar
}

\author{
Ratmiati $^{1}$, Sunarti $^{2}$ \\ ${ }^{1,2}$ Program Pendidikan Guru Madrasah Ibtidaiyah, LAIN Batusangkar \\ e-mail: ratmiati@iainbatusangkar.ac.id
}

\begin{abstract}
ABSTRAK. Thisstudyaims toimprove poetry writing skills with acrostic techniques in elementary school students. This research is descriptive qualitative. This type of research is a class action research (Class Action Research). The research carried out consisted of two cycles, each cycle being carried out three times. The The research procedure includes planning, implementing the action, observing and reflecting. The subjects in this study were 34 grade $\mathrm{V}$ elementary school students.After carrying out the research in the first cycle 21 of 34 students got a score of 72.35 who got a "low" qualification. After that, the second cycle of research was carried out, 33 students got an average score of 80 in the "High" qualification. Based on the results of the research in the first and second cycles it proves that the application of acrostic techniques in learning to write poetry in fifth grade elementary school students is very appropriate because the application of these techniques can improve student learning outcomes in writing poetry for the better
\end{abstract}

Keywords: Acrostic technic, poetry,writing skill

\section{PENDAHULUAN}

Pembelajaran menulis puisi merupakan pembelajaran yang diangggap sulit oleh siswa.Hal ini dikarenakan sedikit banyaknya oleh kemampuan guru dalam melaksanakan pembelajaran yang belum menggunakan teknik yang secara fungsional memudah siswa dalam menghadapi pelajaran. Jika pembelajaran di kelas masih menggunakan cara-cara tradisional, maka dapat dipastikan bahwa prose pembelajaran bersifat teoretis, statis dan membosankan, sehingga ide-ide peserta didik tidak berkembang. Ide untuk menulis dapat diperoleh dari hal-hal yang dekat dengan siswa, seperti pengalaman pribadi atau dari lingkungan sekitar bahkan dari diri dia sesndiri. (pendapat ahli, inter). Namun dalam beberapa kondisi siswa belum mampu mewujudkan ide-ide tersebut ke dalam bentuk kata yang puitis. Ketika siswa akan mewujudkan ide dalam bentuk bahasa puisis siswa belum mampu memilih kata untuk menggali kalimat puisi. Menulis adalah sebuah aktivitas tersendiri maksudnya dalam menulis diperlukan usaha yang keras dari seorang penulis tanpa adanya bantuan dari orang lain (Calkin, 2017)

Dalam menulis, penulis muda atau pemula biasa terlihat bingung penggunakan bahasa formal dan genre percakapan ketika berinteraksi dengan orang-orang ketika berada pada situasi yang berbeda (Olthouse, 2012).Karena ketika digunakan sebagai sumber dalam menulis untuk siswa, harus mengetahui bagian-bagian komunikasi yang dibagi ke dalam dua hal tersebut (Bazerman, 2009). Kemampuan menulis di pengaruhi oleh frekuensi menulis, yang berarti seberapa banyak praktek menulis yang telah dikerjakan oleh seseorang sangat mempengaruhi tulisan yang ia hasilkan, (Limpo, 115).

Terdapat banyak teknik untuk mengajarkan puisi kepada siswa, di antaranya adalah (1) teknik yang memiliki karakteristik, teknik tersebut memiliki kekhasannya tersendiri dibandingkan 
dengan teknik yang lain, (2) mengarahkan siswa dalam mendapatkan ide dari sesuatu yang dekat dengan mereka, mislanya namanya, nama temannya, keluarganya, dll, (3) membantu siswa menemukan kata-kata pertama dalam menulis puisi, (4) membantu siswa dalam memperkaya kosa kata dan membiming sswa dalam menulis puisi. (pendapat ahli, teknik menuis puisi, inter). Puisi adalah pikiran dengan menggunakan imaginasi.Seni adalah salah satunya yang tidak terbentuk tanpa adanya puisi dan imaginasi (Aytekin, 2014).Puisi adalah salah satu karya sastra yang bersifat imajinasi.Puisi menciptakan penyair dalam suasana dan perasaan yang intens berdasarkan pengalaman jiwa dan wawasan penciptanya.Terlepas dari kemampuan siswa untuk fokus pada keindahan, bermain, dan kekuatan emosi dalam bahasa (Elster \& Hanuer, 2002) pembelajaran menulis puisi untuk anak tetap penting.Pembelajaran menulis puisi membantu perkembangan bahasa pada anak dengan lebih cepat (Certo, 2015).Kemampuan menulis puisi siswa pun diperngaruhi oleh kemampuan membaca siswa tersebut (Griffith \& Rasisnski, 2004).

Kemampuan menulis puisi sering juga dikaitkan dengan proses kreatif seorang siswa. secara mendasar dijelaskan bahwa konsep dari kreatif untuk siswa dalam menulis itu adalah asli dan memiliki kualitas yang tinggi (Perkins, 1981). Inilah komponen dasar yang harus diketahui oleh guru dan mengajarkannya kepada siswa. Maley (2012) menyatakan bahwa proses kreatif dalam menulis adalah sebuah sebuah motivasi yang indah, disiplin yang tinggi dan aktivitas seorang anak. Puisi dengan tema bebas dan kepedulian manusia dikaji sebagai sebuah kesempatan siswa untuk projek atau tugas mereka mendapatkan rasa dan emosi (Kirgoz, 2014). Adanya enam alasan pentingnya pembelajaran menulis puisi. Keenam alasan tersebut adalah (1) menulis puisi memberikan kegembiraan yang murni dan menyenangkan, (2) menulis puisi dapat memberikan pengetahuan tentang konsep dunia sekitar siswa, (3) menulis puisi mendorong siswa untuk menghargai bahasa dan mengembangkan kosakata yang tepat dan bervariasi, (4) menulis puisi dapat membantu siswa mengidentifikasi orang-orang dan situasi tertentu, (5) menulis puisi dapat membantu siswa mengekpresikan suasana hati membantu siswa memahami perasaan mereka sendiri, dan (6) menulis puisi dapat membuka dan menumbuhkn kepekaan serta wawasan siswa terhadap lingkungan (Sopandi, 2010).

\section{METODOLOGI}

Penelitian ini merupakan penelitian Tindakan Kelas (PTK). Karakteristik yang khas dari penelitian ini yakni tindakan-tindakan (aksi) yang berulang-ulang untuk memperbaiki proses belajar mengajar di kelas. Adapun subjek penelitia ini kelas $\mathrm{V}$ yang berjumlah 34 orang yang terdiri atas 15 siswa laki-laki dan 19 siswa perempuan.Sasaran utama pada peneliatian ini adalah peningkatan hasil belajar menulis puisi dengan menerapkan teknik akrostik. Desain penelitian pada hakikatnya merupakan tahap atau strategi yang bersifat teknis dalam melakukan suatu penelitian guna memperoleh suatu informasi dan menganalisisnya untuk dapat menarik kesimpulan sebagai hasil akhir dalam penelitian. Adapun desain penelitian yang dilakukan yaitu penelitian tindakan dalam bentuk proses pengkajian berdaur yang terdiri atas empat tahap yaitu perencanaan (planning), tindakan (action), pengamatan (observation), dan refleksi. Proses ini dilakukan secara kolaboratif bersama dengan guru kelas VI SDN 01 Nagrek Kabupaten Bandung. Tahapan yang dilaksanakan dalam penelitian ini yaitu perencanaan, tindakan, observasi, dan refleksi.

Berikut ini adalah tahapan PTK yang dilaksanakan berpatokan pada reflesi awal, maka dilaksanakan penelitian tindakan kelas dengan prosedur sebagai berikut: Tahapan-tahapan yang dilaksanakan dalam penelitian ini adalah sebagai berikut: (1) Siklus I berlangsung 3 kali pertemuan, 2 kali pertemuan digunakan sebagai proses pembelajaran dan 1 kali pertemuan dilakukan untuk tes siklus. Proses tindakan kelas siklus I dalam empat tahap yaitu tahap perencanaan, tindakan, observasi, dan refleksi. Pada tahap perencanaan, peneliti melakukan penelaahan terhadap kurikulum SD pada mata pelajaran Bahasa Indonesia pada pokok bahasan 
puisi, membuat perangkat pembelajaran selama proses penelitian berlangsung, dan melakukan pengembangan terhadap skenario pembelajaran dengan penerapan teknik akrostik. Pada tahap pelaksanaan (tindakan) dengan mengacu pada kenario pembelajaran, peneliti melakukan pengenalan puisi kepada siswa, pengenalan teknik akrostik untuk menulis puisi, mengarahkan siswa untuk membuat satu judul puisi, mengembangkan huruf demi huruf dari nama mereka menjadi sebuah puisi. Pengembangan dari setiap huruf yang merangkai kata demi kata dalam puisi tersebut. Pada proses observasi, peneliti lakukan dengan mengisi lembar observasi terhadap aktivitas guru dan murid. Aktivitas guru yang diamati di antaranya berupa merespon pendapat siswa, membimbing siswa yang mengalami kesulitan dalam menulis puisi melalui teknik akrostik dan mengecek hasil pekerjaan siswa. Kegiatan ini dilakukan selama proses pembelajaran berlangsung. Tahap terakhir adalah refleksi terhadap hasil belajar siswa dan hasil pengamatan sebagai bahan pertimbangan apakah pemberian tindakan yang dilakukan perlu diulangi atau tidak. Jika perlu diulangi maka peneliti akan menyusun kembali rencana (revisi) untuk silklus berikutnya. Demikian seterusnya hingga seluruh siswa dianggap tuntas. (2) Pelaksanaan tindakan siklus II yang pada hakikatnya bergantung pada hasil refleksi siklus I. Pelaksanaan tindakan yang dilakukan pada siklus II adalah mengulangi kembali tahap-tahap yang dilakukan pada siklus I sambil mengadakan beberapa berbaikan yang menjadi permasalahan dalam pelaksanaa siklus I. hal ini bertujuan untuk memperoleh hasil yang lebih baik lagi dibandingkan siklus sebelumnya.

Instrumen yang digunakan dalam pengumpulan data penelitian ini adalah pedoman observasi. Teknik pengumpulan data yang digunakan dalam penelitian ini adalah melalui tes dan observasi. Teknik tes dilaksanakan dengan adanya butir-butir pertanyaan untuk mengukur hasil belajar siswa dengan menerapkan teknik akrostik selama pembelajaran menulis puisi. Setiap siswa diminta menulis puisi dengan akronim huruf awal nama mereka.teknik observasi dilakukan untuk memperoleh informasi keaktifan dan sikap siswa dalam mengikuti proses pembelajaran yang diperoleh melalui pengamatan selama proses pembelajaran. Untuk mengetahui keberhasilan dalam penelitian ini meliputi indicator proses dan hasil dalam penerapan metode akrostik dalam menulis puisi. Adapun kriteria yang digunakan untuk menilai peningkatan hasil belajar siswa adalah berdasarkan kriteria ketuntasan minimal (KKM) kompetensi dasar pada siswa yang diteliti yakni 80 disesuaikan dengan standar ketuntasan belajar minimal bahasa Indonesia.

\section{HASIL DAN PEMBAHASAN}

\section{Siklus I}

Pada kegiatan silus pertama, tahap perencanaan yang dilakukan adalah membuat scenario pelaksanaan tindakan untuk meningkatkan menulis puisi melalui pembelajaran metode akrostik dalam bentuk RPP, membuat lembar observasi, atau instrument untuk melihat bagaimana proses belajar mengajar di kelas ketika pembelajaran berlangsung, wawancara untuk mengumpulkan data tentang tanggapan siswa mengenai pelaksanaan dalam pembelajaran, dan mendesain alat evaluasi untuk melihat apakah kemampuan menulis puisi siswa cukup baik.

Pada awal pembelajaran siswa terlihat sangat senang dan antusias mendengarkan guru menjelaskan tujuan pembelajaran dan manfaat pembelajaran puisi dengan menggunakan teknik akrostik. Begitu juga ketika peneliti mengaitkan pembelajaran dengan tanya jawab peroranan, kompetensi sikap siswa pada umumnya mulai terbntuk, hanya ketika siswa belajar dalam kelompok dua hingga empat orang atau lebih, ada beberapa siswa yang belum mempu berinteraksi dengan teman sekelompoknya dan sebagian siswa menggantungkan atau mengharapkan hasil kerja kawannya. Sebagian siswa masih kurang berminat untuk mengikuti pembelajaran hal ini dilihat dari beberapa kegiatan di kelas, masih ada siswa yang melakukan kegiatan lain pada saat proses pembelajaran berlangsung seperti permisi. Namun hal ini hanya terjadi pada satu sampai dua anak yang memang tidak memiliki semangat belajar. 
Hasil penelitian pada siklus I menunjukkan bahwa skor rata-rata hasil belajar siswa kelas VI SDN 01 Nagrek. Melalui penerapan teknik akrostik dalam menulis puisi sebanyak 34 siswa, diperoleh nilai rata-rata adalah 72,35. Skor tertinggi 90 dan skor terendah 60 dengan standar rentang skor 20. Hal ini menunjukkan bahwa rata-rata hasil belajar siswa berada pada kategori sedang. Persentase skor rata-rata yang peroleh siswa dapat dilihat pada Tabel 3.1 berikut.

Tabel 1 Statistik Skor Hasil Belajar Siswa pada Siklus I

\begin{tabular}{ll}
\hline Statistik & Nilai Statistik \\
\hline Subjek & 34 \\
Skor ideal & 100 \\
Skor tertinggi & 90 \\
Skor terendah & 60 \\
Skor rata-rata & $72,35 \%$ \\
\hline
\end{tabular}

Tabel 1 menunjukkan bahwa skor rata-rata adalah 72,35 dari hasil belajar ideal 100, skor tertinggi 90 dan skor terendah 60 dengan standar rentang skor 20 yang berarti hasil belajar yang terampil menulis puisi yang dicapai siswa kelas $\mathrm{V}$ tersebar dari skor rendah 60 sampai skor tinggi 90. Pengelompokkan perolehan skor siswa tersebut dibagi menjadi lima kategori, di ataranya adalah sangat rendah, rendah, sedang, tinggi dan sangat tinggi. Masing-masing kategori terdapat frekuensi serta persentase dari perolehan skor tersebut.. perolehan skor berdasarkan kategori, frekuensi, dan persentasenya dapat dilihat pada tabel 3.2 berikut.

\section{Tabel 2 Distribusi Frekuensi dan Persentase Hasil} Kemampuan Awal Siswa Siklus I

\begin{tabular}{llll}
\hline Interval Skor & Kategori & Frekuensi & Persentase \\
\hline $\mathbf{0 - 5 5}$ & Sangat Rendah & 0 & 0 \\
$\mathbf{5 6 - 6 5}$ & Rendah & 12 & $35,2 \%$ \\
$\mathbf{6 6 - 7 5}$ & Sedang & 8 & $23,5 \%$ \\
$\mathbf{7 6 - 8 5}$ & Tinggi & 8 & $23,5 \%$ \\
$\mathbf{8 6 - 1 0 0}$ & Sangat Tinggi & 6 & $17,6 \%$ \\
Jumlah & & 34 & 100 \\
\end{tabular}

Berdasarkan table tersebut, tidak ada siswa yang memberoleh skor pada kategori sangat rendah. Pada kategori sangat rendah terdapat 12 siswa atau sekitar 35,3\% siswa. Perolehan skor pada kategori ini merupakan perolehan skor paling banyak. Dengan rentang perolehan nilai berada pada interval skor 56-65. Sedangkan, pada kategori sedang dan tinggi dengan perolehan masing-masing kategori 8 siswa atau sekitar 23,5\%. Selain itu, pada kategori sangat tinggi terdapat 6 orang dengan persentase 17,6\% dengan interval skor berada pada 86-100.

Refleksi siklus I adalah sebagai berikut: (1) Umumnya siswa menunjukkan antusias belajar yang positif, seperti menanggapi pertanyaan, keberanian mengajukan pertanyaan atau tanggapan kepada guru. Namun karena siswa belum terbiasa dengan tindakan yang diberikan maka kelas menjadi gaduh sehingga pengelolaan kelas lebih ditekankan pada siklus II. Masih ada beberapa siswa yang sulit dalam menyelesaikan tugas yang diberikan, berkomunikasi dengan teman sekelompoknya. Untuk itu guru harus membimbing siswa tersebut. Dari hasil tes siklus I masih terdapat beberapa siswa yang mendapatkan nilai dibawah KKM. Hal ini disebabkan karena dalam kegiatan pembelajaran selama 3 kali pertemuan sebelumnya beberapa siswa tersebut kurang aktif dalam pembelajaran dan ada juga yang tidak hadir dalam beberapa pertemuan. (2) Dari segi proses pembelajaran yang telah dilakukan dengan mengacu pada hasil observasi dapat disimpulkan bahwa penelitian tersebut belum memperoleh keberhasilan dari segi proses yang mana indicator penilaiannya terdiri atas penilaian kegiatan guru dan kegiatan murid. Kegiatan guru meliputi proses pembelajaran yang dilaksanakan belum berjalan secara optimal seperti yang direncanakan, sebab masih ada tiga indikator yang tidak terlaksana dengan baik. Sedangkan untuk 
kegiatan siswa masih terdapat siswa yang sulit menyelesaikan tugas mereka. untuk itu diperlukan bimbingan guru terhadap siswa tersebut. Selain itu siswa juga belum terbiasa dengan kegiatan berkelompok sehingga banyak siswa yang belum aktif dalam kegiatan berkelompok ataupun diskusi antar kelompok.

Dari hasil tindakan yang telah dilakukan di siklus I berupa puisi-puisi. Kemampuan siswa dalam menyusun kata demi kata masih kaku dan tidak ada kesatuan antara satu larik dengan larik berikutnnya. Pada kegiatan tindakan siklus I guru meminta siswa menyusun huruf demi huruf nama lengkap mereka dengan pola akrostik vertical. Contoh berikut ini penulisan puisi oleh siswa menggunakan pola akrostik dengan tema tentang alam. Pemilihan tema alam dimaksudkan agar memudahkan siswa menulis puisi dengan langsung melihat alam luas di luar kelas mereka. lokasi sekolah merupakan sekolah yang asri terdapat pemandangan sawah dan pepohonan yang hijau juga menjadi pertimbangan guru untuk memilih tema alam sebagai objek siswa membuat puisi.

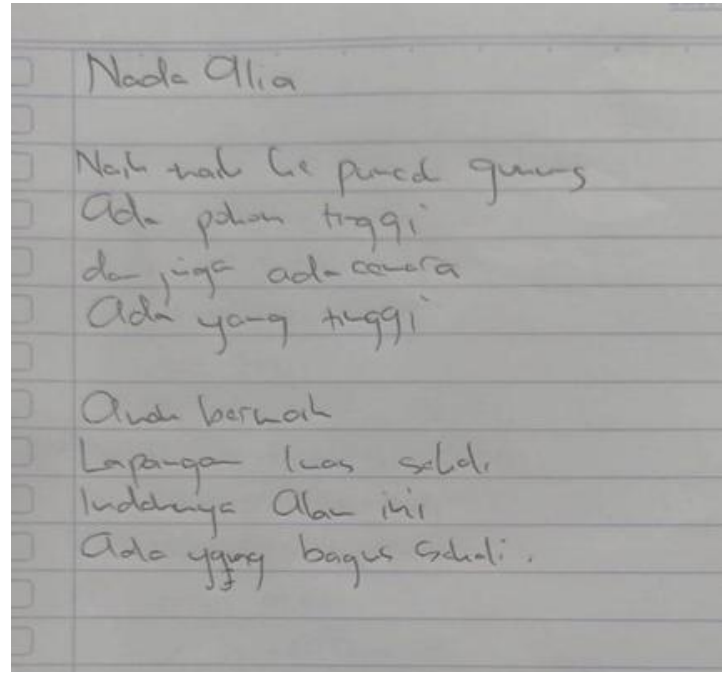

Nada Alia

Naik-naik ke puncak gunung

Ada pohon tinggi

Dan juga ada pohon cemara

Ada yang tinggi

Anak-anak bermain

Lapangan luas sekali

Indah alamku

Ada yang bagus sekali

\section{Gambar 1: Puisi Nada Alia}

Pada langkah pertama siswa bernama Nada telah menulikan huruf demi huruf namanya dengan menggunakan teknik akrostik menjadi sebuah puisi tentang alam. Dari puisi tersebut siswa sudah bisa membuat sebuah puisi bertemakan alam berdasarkan sebuah lagu yang pernah ia dengar yakni "Naik-naik ke Puncak Gunung". Walaupun sudah diingatkan oleh guru untuk menulis judul siswa tidak menuliskan judul puisi yang telah dibuatnya.

Berdasarkan gambar pada puisi tersebut. Terdapat kekurangsesuaian antara satu larik dengan larik lainnya. Belum ada kesinambungan isi antara satu larik dengan larik yang lain. Pengulangan kata yang sama masih terjadi, contoh kata "tinggi" yang diulang dua kali pada bait yang sama. Hal ini mengakibatkan isi puisi menjadi kurang baik. Oleh karena itu pada siklus I ini perlu adanya tindakan yang lebih ditekankan kepada anak dalam mengembangkan huruf menjadi kata, kata menjadi kalimat, dan dari satu kalimat (larik) dalam puisi haruslah memiliki kesinambungan makna. Hal ini dilakukan dan direvisi pada siklus II.

Puisi siswa bernama Rohdiana juga mengankat tema tentang alam. Puisi siswa ini sudah memiliki judul yakni "Alam". Namun dari huruf nama lengkap yang ditulis menjadi puisi tersebut menggunakan teknik akrostik masih memiliki ketidak sesuaian makna di masing-masing kata yang muncul. Siswa masih menulis kata, kalimat menjadi sebuah puisi sesuai dengan yang teringat dan terlintas dalam pikiran saja. 


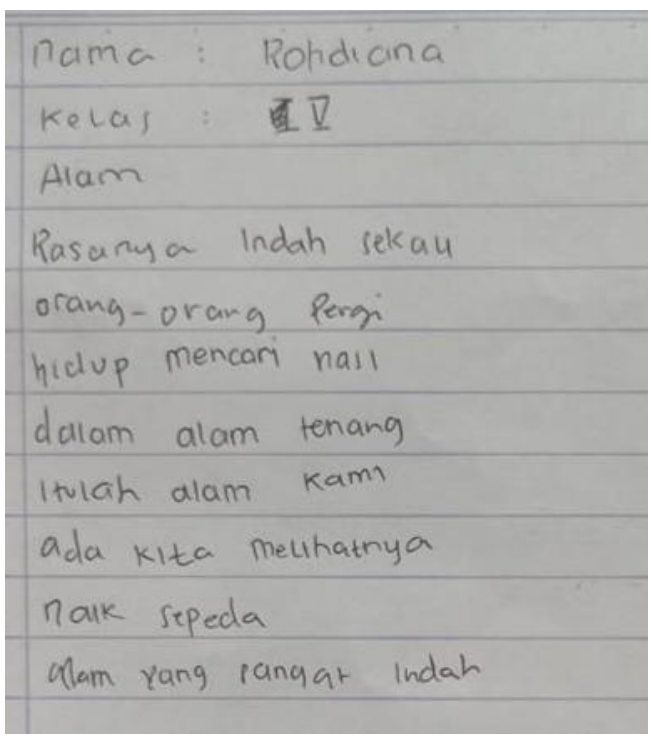

Gambar 2 Puisi Rohdiana

\section{Siklus II}

Setelah siklus I dilaksanakan dan dievaluasi, terdapat beberapa langkah pembelajaran pada tahap pelaksanaan yang menjadi perhatian guru, terutama pada tahap pelaksanaan tindakan pembelajaran menulis puisi dengan menggunakan teknik akrostik. Berbeda dengan hasil belajar siswa pada siklus I, pada pelaksanaan siklus II puisi siswa telah memiliki kesatuan dan telah menunjukkan kesesuaian antara larik dengan tema yang diangkat. Tema pada siklus kedua ini masih tentang alam. Siswa diberi kebebasan oleh guru untuk menuliskan puisi berdasarkan pengamatan mereka langsung. Adapun puisi siswa pada siklus kedua dapat dilihat sebagai berikut.

\section{Alam yang Kering (Karya Sarah Nuriah)}

Suara air tidak ada lagi

Antara sawah dan pematang sawah

Riang gembira daun padi

Air hujan tampak bercucuran

Hidupkan kembali padi

Negeri ini sangat membutuhkan air

Untuk menghidupkan para petani di sawah

Rumput hijau di tanah lapang juga

Ilalang di pematang juga mengering

Angin berhembus sepoi-sepoi

Hujan turun akhirnya, Alhamdulillah.

Puisi siswa bernama Sarah Nuriah yang secara umum antara larik satu dengan yang lainnya telah memiliki keserasian dan kepaduan. Puisi yang bertemakan alam yang kering tersebut dibuat oleh Sarah menggunakan teknik akrostik huruf awal namanya dikembangkan menjadi sebuah puisi bertemakan alam.

Siklus II dilaksanakan untuk mengetahui tingkat pencapaian siswa. Hasil analisis deskripsti terhadap skor perolehan hasil belajar siswa setelah digunakan teknik akrostik dalam pembelajaran menulis puisi. Sebanyak 34 siswa SDN 01 Nagrek melalui tahapan penggunaan teknik akrostik pada siklus I sebesar 72,35 skor rata-rata yang dicapai responden tersebar dengan skor tertinggi 
90 dan skor terendah 60. Selanjutnya dilakukan pengkategorian terhadap skor yang diperoleh oleh responden. Tersebar dari atas skor sangat rendah, rendah, sedang, tinggi dan sangat tinggi. Sebaran nilai paling banyak tersebar terletak pada kategori rendah dengan persentase 35,2\% sebanyak 12 siswa berada pada kategori rendah. Hal ini menunjukkan bahwa rata-rata hasil belajar puisi siswa berada pada kategori rendah, oleh karena itu perlu ditingkatkan dan diatasi pada siklus kedua. Persentase skor rata-rata hasil belajar menulis puisi siswa setelah penggunaan metode akrostik adalah 80. Apababila hasil belajar siswa pada siklus I dianalisis, maka persentase ketuntasan belajar menulis puisi siswa stelah menggunakan metode akrostik pada silus II menunjukkan bahwa dari 34 siswa terdapat $80 \%$ siswa tuntas belajar dan $20 \%$ belum tuntas belajar. Ini berarti ketuntasan belajar. Persentase skor rata-rata yang peroleh siswa dapat dilihat pada Tabel 3 berikut.

Tabel 3 Statistik Skor Hasil Belajar Siswa pada Siklus II

\begin{tabular}{cc}
\hline Statistik & Nilai Statistik \\
\hline Subjek & 34 \\
Skor ideal & 100 \\
Skor tertinggi & 100 \\
Skor terendah & 70 \\
Skor rata-rata & $80 \%$ \\
\hline
\end{tabular}

Tabel 3 menunjukkan bahwa skor rata-rata yang diproleh adalah $80 \%$ dari hasil belajar ideal 100. Skor tertinggi 100 dan skor terendah adalah 70 dengan standar rentang skor 30 yang berarti hasil belajar siswa dalam menulis puisi tersebar dari skor terendah 70 sampai skor ideal 100 .

Pada siklus II ini, siswa kembali dipandu untuk menulis puisi dengan mengurangi kesalahan-kesahan yang terjadi pada siklus I. selain itu, juga terlihat keseriusan siswa dalam memperhatikan pelajaran dan mengerjakan soal yang diberikan hasil belajar mereka dengan penerapan teknik akrostik dengan nama sendiri pada siklus I adalah $72 \%$ dan pada siklus II meningkat menjadi $80 \%$. Secara umum dapat dikatakan bahwa seluruh kegiatan pada siklus II ini mengalami peningkatan dibanding pad siklus I. hal ini terlihat pada kehadiran siswa meningkat, keseriusan siswa dalam memperhatikan pembelajaran, minat, sikap, dan motivasi mereka juga meningkat. Apabila dikelompokkan kemampuan siswa pada siklus dua ini maka akan diperoleh distribusi frekuensi skor yang ditunjukkan pada tabel 3.4 berikut.

\section{Tabel 4 Distribusi Frekuensi dan Persentase Hasil Kemampuan Awal Siswa Siklus II}

\begin{tabular}{llll}
\hline Interval Skor & Kategori & Frekuensi & Persentase \\
\hline $\mathbf{0 - 5 5}$ & Sangat Rendah & 0 & 0 \\
$\mathbf{5 6 - 6 5}$ & Rendah & 0 & 0 \\
$\mathbf{6 6 - 7 5}$ & Sedang & 14 & $41,1 \%$ \\
$\mathbf{7 6 - 8 5}$ & Tinggi & 11 & $32,3 \%$ \\
$\mathbf{8 6 - 1 0 0}$ & Sangat Tinggi & 9 & $26,4 \%$ \\
Jumlah & & 34 & $100 \%$ \\
\hline
\end{tabular}

Berdasarkan tabel 3.4 tersebut diperoleh data pemberian tugas siswa di kelas dengan menggunakan teknik akrostik nama sendiri, tidak ada siswa pada kategori sangat rendah dan kategori rendah, pada kategori sedang terdapat 14 siswa atau sekitar 41,1\%, terdapat 11 siswa pada kategori tinggi atau setara dengan 32,3\%, sedangkan pada kategori sangat tinggi terdapat 9 siswa dengan persentase perolehan nilainya $26,4 \%$.

\section{PEMBAHASAN}

Data yang diperoleh dari hasil tes hasil belajar dianalisis dengan menggunakan statistik deskripstif.Sedangkan hasil observasi dianalisis secara kualitatif.Adapun untuk menentukan 
kategori adalah dengan menggunakan teknik kategorisasi standar berdasarkan ketetapan kementrian pendidikan nasional.

\section{Refleksi Pelaksanaan Siklus I}

Pelaksanaan refleksi dilakukan penelitia bersama partner guru dengan melihat perbandingan antara penerapan teknik akrostik peningkatan kemampuan siswa pada pembelajaran menulis puisi permulaan siklus I dapat diketahui dengan cara membandingkan perolehan persentase kemampuan siswa sebelum diberikan tindakan dan setelah diterapkan teknik akrostik. Berdasarkan hasil penelitian dan saran guru, beberapa hal yang perlu diperhatikan pada tindakan selanjutnya adalah (1) etode yang digunakan ditambah metode kelompok agar semua siswa lebih aktif dan guru lebih maksimal dalam membimbing siswa. (2) mengarur waktu seefisien mungkin agar pembelajaran maksimal dan siswa memilii waktu untuk bermain.

\section{Refleksi Pelaksanaan Siklus II}

Upaya yang dilakukan untuk meningkatkan hasil belajar keterampian menulis dengan teknik akrostik tidak terlepas dari perhatian dan perubahan sikap siswa dalam proses pembelajaran. Hal ini dapat dilihar pada lembar observasi yang dilakukan selama pelaksanaan tindakan. Kegiatan siswa pada siklus II ini, semangat dan perhatian siswa dalam proses pembelajaran meningkat. hal ini tampak dari perhatian siswa dalam memperhatikan materi dan siswa yang mengajukan pertanyaan kepada guru. Pada saat guru memantau siswa dalam mempelajari materi pada umumnya aktif.Selain itu, siswa yang melakukan kegiatan yang tidak relevan dengan pembelajaran mengalami penurunan.

Berdasarkan hasil observasi yang mempengaruhi semngat belajar meningkat yaitu: (1) guru memberikan penguatan dan memberikan motivasi kepada siswa, (2) guru mengubah struktur dan variasi kelompok yaitu dengan memasukkan satu atau lebih tutor yang bisa membimbing teman kelompoknya agar setiap siswa mamp menulis puisi dengan baik. (3) guru menampilkan media yang menarik sesuai dengan konteks kebiasaan anak, (4) guru memberikan penialain secara proposional terhadap tugas yang dikerjakan oleh siswa.

\section{KESIMPULAN}

Berdasarkan hasil analisis data pada bab sebelumnya, dapat disimpulkan bahwa pembelajaran dengan menggunakan teknik akrostik dapat meningkatkan kemampuan menulis puisi siswa kelas VI SDN 01 Nagrek. Hasil penelitian menunjukkan bahwa aktivitas guru pada siklus I masih berada pada kategori rendah dan setelah dilakukan pembelajaran dengan menerapakan teknik akrostik, siswa dilatih merangkai sebuah puisi berdasarkan huru-huruf awal nama siswa tersebut. Pembelajaran menulis puisi ini tidak hanya dilakukan satu kali pertemuan saja, namun terdiri atas beberapa kali pertemuan dan dilanjutkan pada siklus berikutnya jika masih terdapat langkah yang perlu dipecahkan pada siklus I. Pada siklus I tingkat ketuntasan siswa mencapai 64,7\% dengan kemampuan kurang memuaskan secara keseluruhan. Demikian juga aktivitas siswa pada siklus Iberada pada kategori cukup dan pada pelaksanaan siklus II mengalami peningkatan menjadi kategori baik. Pada siklus II siswa mengalami peningkatan dari kegiatan awal sangat rendah menjadi sangat tinggi dengan tingkat ketuntasan $100 \%$. Peningkatan hasil belajar menulis puisi siswa pun dilihar dari rata-rata siklus I (72\%) dan pada siklus II meningkat menjadi $(80 \%)$. Terjadinya peningkatan persentase kehadiran siswa, perhatian, minat dan keaktifan dalam belajar sertaa semangat belajar siswa dalam proses pembelajaran. Sesuai dengan hasil penelitian tentang penggunaan teknik akrostik dalam pembelajaran menulis puisi di kelas VI SDN 01 Nagrek Jawa Barat maka dikemukakan saran sebagai berikut: (1) kepada guru sekolah dasar agar dapat menerapkan teknik akrostik sebagai salah satu alternatif dalam pembelajaran menulis puisi bagi siswa yang mengalami kesulitan dalam memulai menulis puisi (2) kiranya seorang juga dapat menjadikan teknik akrostik dalam pembelajaran menulis puisi yang kreatif lainnya; (3) kepada 
peneliti lain dapat mengadakan penelitian lanjutan dengan menerapkan metode akrostik dalam pembelajaran menulis puisi di sekolah dasar yang lebih luas.

\section{REFERENSI}

Aytekin, A. C. 2014. On the tracks of literary structure in literary work (a sumerian poem). Social and Behavioral Scienses, 158, 43-50.

Arikunto, S. 2002. Penelitian Tindakan Kelas. Jakarta. Rineka Cipta

Bazerman, C. 2009. Issues brief: Discourse communictaes. Retrieved from: http:// college/brief/dc.

Calkin, A. G. 2017.Writing on writing.Internasional Journal of Educational Research.

Elster, C., \& Hanauer, D. 2002. Voicing text, voices Aroundtexts: Reading poems in elementary school classroom. Research in the Teaching of English, 37 (1), 89-134.

Griffith, L., \& Rasinski, T. 2004. A focus on fluency: How one teacher incorporated fluency with her reading curriculum. The Reading Teacher, 58, 126-137.

Certo, J. 2015. Poetic language, Interdiscursivity and intertextuality in fith grades poetry: An interpretative study. Journal of Literacy Research, 47 (1), 49-82).

Kirgoz, Y. 2014. Exploring Poem to promote language learners' creative writing.14th Internasional Laguage, Literature and Stylistics Symposium.157, 994-401.

Limpo, T. 2018. Development of a short measure of writing apprehension: Validity evidence. Learning and Instruction. Universidade do Porto, Rua Alfredo Allen, 4200-392 Porto, Portugal. https://doi.org/10.1016/j.learninstruc.2018.06.001. and association with writing frequency, process, and performance

Malley, A. 2012.Creativw writing for students and teachers.Humanizing Language Teaching.14, 3, 1-18.

Nazarenko, T. 2006. Writing poetry without words: pictographicpoems by rea nikonova and sergej sigej: Russian Literature LIX (2006) II/III/IV. doi:10.1016/j.ruslit.2006.06.009.

Olthouse, J. M. 2012. Talented young writer's relationship with writing, Journal for Education of the Gifted. 35 (1) 66-80.

Perkins. D. N. 1981. The mind's best work.Camridge. MA: Harvard University Press. (online)

Sopandi. 2010. Memahami Puisi. Bogor: Quadra. 